\title{
A global blended tropopause based on ERA data, Part II: trends and tropical broadening
}

Article

Accepted Version

Wilcox, L., Hoskins, B. and Shine, K. (2012) A global blended tropopause based on ERA data, Part II: trends and tropical broadening. Quarterly Journal of the Royal Meteorological Society, 138 (664). pp. 576-584. ISSN 1477-870X doi: https://doi.org/10.1002/qj.910 Available at https://centaur.reading.ac.uk/25587/

It is advisable to refer to the publisher's version if you intend to cite from the work. See Guidance on citing.

To link to this article DOI: http://dx.doi.org/10.1002/qj.910

Publisher: Royal Meteorological Society

All outputs in CentAUR are protected by Intellectual Property Rights law, including copyright law. Copyright and IPR is retained by the creators or other copyright holders. Terms and conditions for use of this material are defined in the End User Agreement.

www.reading.ac.uk/centaur 
Central Archive at the University of Reading

Reading's research outputs online 


\title{
A global blended tropopause based on ERA data. Part II: Trends and tropical broadening
}

\author{
L. J. Wilcox, B. J. Hoskins, and K. P. Shine
}

\begin{abstract}
A new tropopause definition involving a flow-dependent blending of the traditional thermal tropopause with one based on potential vorticity has been developed and applied to the European Centre for Medium-Range Weather Forecasts (ECMWF) reanalyses (ERA), ERA-40 and ERA-Interim. Global and regional trends in tropopause characteristics for annual and solsticial seasonal means are presented here, with emphasis on significant results for the newer ERA-Interim data for 1989-2007. The global-mean tropopause is rising at a rate of $47 \mathrm{~m}$ decade $^{-1}$, with pressure falling at $1.0 \mathrm{hPa}$ decade $\mathrm{h}^{-1}$, and temperature falling at $0.18 \mathrm{~K} \mathrm{decade}^{-1}$. The Antarctic tropopause shows decreasing heights, warming, and increasing westerly winds. The Arctic tropopause also shows a warming, but with decreasing westerly winds. In the tropics the trends are small, but at the latitudes of the sub-tropical jets they are almost double the global values. It is found that these changes are mainly concentrated in the eastern hemisphere. Previous and new metrics for the rate of broadening of the tropics, based on both height and wind, give trends in the range $0.9^{\circ}$ decade $^{-1}$ to $2.2^{\circ}$ decade $^{-1}$. For ERA-40 the global height and pressure trends for the period 1979-2001 are similar: $39 \mathrm{~m} \mathrm{decade}^{-1}$ and $-0.8 \mathrm{hPa}$ decade $^{-1}$. These values are smaller than those found from the thermal tropopause definition with this data set, as was used in most previous studies.
\end{abstract}

\section{Introduction}

The tropopause, the boundary between the troposphere and the stratosphere, can be identified from changes in temperature lapse rate, potential vorticity, and chemical concentrations. Increases in tropopause height (decreases in tropopause pressure) are associated with a warming of the troposphere and a cooling of the stratosphere, and as such are an important indicator of global change.

The primary cause of observed increases in tropopause height is thought to be increases in well-mixed greenhouse gases. Santer et al. (2004) found that stratospheric cooling and tropospheric warming are robust signals of increasing atmospheric carbon dioxide, and that the pattern of increases in tropopause height is consistent with model predictions of the response to increases in carbon 
dioxide alone. Santer et al. (2003a) found that anthropogenic changes in ozone and well-mixed greenhouse gases accounted for $80 \%$ of the increase in tropopause height between 1979 and 1999. Sausen and Santer (2003) also found that the observed increases in global tropopause height cannot be explained by natural variability. It has been suggested that changes at the tropopause provide a sensitive indicator of climate change (e.g. Randel et al., 2000, Santer et al., 2003b, 2004), as time-series of global-mean tropopause height contain much less natural variability than those of tropospheric or surface temperature. Sausen and Santer (2003) suggested that changes in tropopause height could be detected approximately 20 years in advance of changes in surface temperature.

In this paper we present regional and global tropopause trends derived from the European Centre for Medium-Range Weather Forecasts (ECMWF) ERA-40 and ERA-Interim reanalyses.

\section{Data sets}

Climatologies of tropopause height, pressure, temperature, and westerly winds have been produced from the ERA-40 and ERA-Interim reanalyses. ERA-40 was used with a horizontal resolution of $1.125^{\circ} \times 1.125^{\circ}$ on 23 isobaric levels for September 1957 to August 2002 (Uppala et al., 2005). ERA-Interim data (Dee et al., 2011), with a horizontal resolution of $0.703^{\circ} \times 0.703^{\circ}$ on 37 isobaric levels, has been analysed for January 1989 to December 2007. Data is also provided by ECMWF on the $2 \mathrm{PVU}$ potential vorticity $(\mathrm{PV})$ surface $\left(1 \mathrm{PVU}=1 \times 10^{6} \mathrm{~K}\right.$ $\mathrm{m}^{2} \mathrm{~kg}^{-1} \mathrm{~s}^{-1}$ ). This has been interpolated directly from 60 model level data for ERA-40 and ERA-Interim. 6 hourly data is used in both cases.

When evaluating tropopause position there are several key differences between the ERA-40 and ERA-Interim systems, which are discussed in Part 1 (Wilcox et al., 2011). Analyses presented here use ERA-Interim unless stated otherwise. The difference between the ERA-40 and ERA-Interim tropopause climatologies is discussed in Part 1.

\section{Tropopause definitions}

There are several ways to define the tropopause. The majority of studies of tropopause trends use a standard thermal definition. However, the dependence of the thermal tropopause definition on the temperature lapse rate can make it difficult to identify the tropopause in polar night regions. Additionally, it can be multi-valued in the vicinity of the sub-tropical jet.

It is also common for the tropopause to be assigned to the position of a chosen value of PV. This 'dynamic tropopause' is generally accepted to lie between PV values of $1 \mathrm{PVU}$ and 4 PVU in the Northern Hemisphere (NH) (e.g. Hoskins et al., 1985, Kunz et al., 2011). The choice of value is influenced by the context of interest, and the vertical resolution of the data. Unfortunately, a tropopause 
definition based entirely on PV cannot be used globally, as PV surfaces become vertical close to the equator.

Here we use a flow-dependent combination of a thermal tropopause definition and a dynamic tropopause definition to give a globally-applicable 'blended' tropopause definition; for details see Wilcox et al. (2011). The thermal tropopause is found using the WMO (1957) definition and linear interpolation between isobaric levels (e.g. Reichler et al.), and the dynamic tropopause is placed at the height where $|\mathrm{PV}|=2 \mathrm{PVU}$. The height of the blended tropopause, $h_{b}$, is chosen to be that of the dynamic tropopause, $h_{d}$, if the potential temperature there, $\theta_{d}$, is less than $350 \mathrm{~K}$. This is expected to apply in middle and high latitudes. When $\theta_{d}$ is greater than $370 \mathrm{~K}, h_{b}$ is usually chosen to be the height of the thermal tropopause. This is the case in the deep tropics. For $\theta_{d}$ between these values, the tropopause height is determined by linear interpolation. The thermal tropopause can be difficult to locate in the region of the sub-tropical jet using ERA data, which can lead to the appropriate lapse rate being found at a much higher altitude. For this reason, for $\theta_{d}$ above $370 \mathrm{~K}$, and for the interpolation between there and $350 \mathrm{~K}$, we use instead $h_{m}$, which is the lower of the heights of the dynamic and thermal tropopause. In mathematical form:

$$
h_{b}= \begin{cases}h_{d} & \theta_{d}<350 \mathrm{~K} \\ \left(\frac{\theta_{d}-350}{20}\right) h_{m}+\left(1-\frac{\theta_{d}-350}{20}\right) h_{d} & 350 \leq \theta_{d} \leq 370 \mathrm{~K} \\ h_{m} & \theta_{d}>370 \mathrm{~K}\end{cases}
$$

The wind field on the tropopause surface has the special property that it includes both the sub-tropical and polar jets, which would ordinarily be visualised on two different pressure levels. Here its zonal component will be considered in addition to tropopause height, pressure and temperature.

Climatologies of the ERA-Interim blended tropopause, and the difference between the thermal, dynamic, and blended tropopause surfaces, are presented in Part 1 (Wilcox et al., 2011). Blending can occur as far poleward as $45^{\circ}$, but typically only occurs equatorward of $30^{\circ}$.

\section{Global-mean trends}

Trends in tropopause height, pressure, temperature, and tropopause-level zonal wind have been calculated at grid-scale resolution for the annual, December to February (DJF), and June to August (JJA) mean. Trends were assumed to be linear and were calculated using the least squares method. A 1-tailed t-test was used to identify when trends were significantly more positive or negative than zero. These grid-scale resolution trends were averaged to generate zonal- and global-mean trends. In the case of global and regional means a cosine-latitude weighting is applied to the grid-point data. Positive trends in global tropopause height are identified in both the ERA-Interim (Table 1) and ERA-40 time-series.

Trends in global tropopause pressure previously identified in reanalyses range from $+0.1 \mathrm{hPa}$ decade ${ }^{-1}(1979-1993)$ (Hoinka, 1999) to $-2.66 \mathrm{hPa}$ decade $^{-1}$ (1979-2001) (Santer et al., 2004), although trends of about -1 to $-2 \mathrm{hPa}$ decade $^{-1}$ are typically reported (e.g. Santer et al., 2003b; Sausen and Santer, 2003; Son et al., 2009). 


\begin{tabular}{cccc}
\hline ERA-Interim (1989-2007) & Annual & JJA & DJF \\
\hline \hline Blended height & $47^{* *}$ & $48^{* *}$ & $43^{*}$ \\
Dynamic height & $44^{* *}$ & $46^{* *}$ & $38^{*}$ \\
Thermal height & $46^{* *}$ & $50^{* *}$ & $42^{*}$ \\
\hline Blended pressure & $-0.97^{* *}$ & $-1.1^{* *}$ & $-0.74^{*}$ \\
Thermal pressure & $-0.61^{*}$ & -0.92 & -0.27 \\
\hline Blended temperature & $-0.18^{*}$ & $-0.15^{*}$ & $-0.24^{*}$ \\
\hline
\end{tabular}

Table 1: Trends in global-mean tropopause variables from ERA-Interim (19892007). Height trends are in $\mathrm{m}$ decade $^{-1}$, pressure trends are in $\mathrm{hPa}$ decade $^{-1}$, and temperature trends are in $\mathrm{K}$ decade ${ }^{-1}$. Trends significantly different from 0 at the $1 \%$ level are indicated by ${ }^{* *}$. Significance at the $5 \%$ level is indicated by *.

Tropopause trends from observations tend to be restricted to specific regions. For example, trends in the tropical tropopause were evaluated by Randel et al. (2000) and Seidel et al. (2001) using radiosonde data, and Zhou et al. (2001) using rawinsonde data. However, some global analyses do exist. Seidel and Randel (2006) identified a trend of $-1.7 \mathrm{hPa}$ decade $^{-1}$ (1980-2004) in the globalmean tropopause using radiosonde data, and Schmidt et al. (2008) place the global increase in tropopause height between 40 and $70 \mathrm{~m} \mathrm{decade}^{-1}$ using Global Positioning System (GPS) radio occultation data. See Table 2 for a summary of trends in the global-mean tropopause from a selection of earlier studies. Note that comparisons between trends from different studies need to be made with care. The results of Seidel and Randel (2006) demonstrate the influence of the end points of the data on the calculated trends. Their estimates of the trend in the global tropopause have a range in excess of a factor of two, from -0.77 $\mathrm{hPa}$ decade $^{-1}$ (1980-1993) to $-1.89 \mathrm{hPa}$ decade $^{-1}(1980-2000)$. The trend in the blended tropopause of $-0.97 \mathrm{hPa}$ decade $^{-1}$ (1989-2007) falls at the lower end of the range of recent estimates.

The trends in global-mean blended tropopause height identified in both ERA data sets are generally smaller than those given in previous work, with the exception of those calculated by Hoinka (1999). Santer et al. (2004), using ERA-40, calculated trends of $-2.36 \mathrm{hPa}$ decade $^{-1}$ from data with 60 vertical levels, and $-2.66 \mathrm{hPa}$ decade $^{-1}$ from data with 23 vertical levels for 1979-2001, two to three times larger than the $-0.8 \mathrm{hPa}$ decade $^{-1}$ found here for the same period.

Our comparatively small trends in ERA-40 are the result of the tropopause definition used. Santer et al. (2004) use the thermal definition. The thermal tropopause height trend derived here is $+104 \mathrm{~m} \mathrm{decade}^{-1}\left(-2.61 \mathrm{hPa}\right.$ decade $\left.^{-1}\right)$ in ERA-40 (1979-2001). The thermal tropopause pressure trend is in good agreement with the ERA-40 trends found by Santer et al. (2004) using the same 23 level gridded data $\left(-2.66 \mathrm{hPa}\right.$ decade $\left.^{-1}\right)$. The thermal tropopause trend is also comparable to the ERA-40 (1979-1999) trend from Son et al. (2009), 


\begin{tabular}{ccccc}
\hline Study & Data & Period & $\begin{array}{l}\text { Global trend } \\
\left(\mathrm{hPa}_{\text {decade }}{ }^{-1}\right.\end{array}$ \\
\hline \hline Hoinka (1998) & ERA-15 & $1979-1993$ & -0.1 & \\
Hoinka (1999) & ERA-15 & $1979-1993$ & 0.1 & \\
\hline Sausen and Santer (2003) & NCEP/NCAR & $1979-1997$ & -1.82 & \\
& GSOP & $1979-1997$ & -1.47 & \\
\hline Santer et al. (2003a) & PCM & $1979-1999$ & -0.95 & \\
\hline Santer et al. (2003b) & NCEP/NCAR & $1979-2000$ & -2.16 & \\
& ECMWF & $1979-2000$ & -1.13 & \\
& NCEP & $1979-1993$ & -1.05 & \\
\hline Santer at al. (2004) & ERA-40 (60 lev) & $1979-2001$ & -2.36 & \pm 0.47 \\
& ERA-40 (23 lev) & $1979-2001$ & -2.66 & \pm 0.48 \\
& NCEP & $1979-2001$ & -1.79 & \\
& PCM & $1979-2001$ & -1.13 & \\
\hline Seidel and Randel (2006) & Radiosonde & $1980-2004$ & -1.7 & \pm 0.6 \\
& & $1980-1993$ & -0.77 & \pm 1.42 \\
& & $1980-1997$ & -1.60 & \pm 1.00 \\
& & $1980-2000$ & -1.89 & \pm 0.81 \\
& & $1980-2001$ & -1.83 & \pm 0.75 \\
\hline Son et al. (2009) & CCM & $1979-1999$ & -1.53 & \pm 0.42 \\
& NCEP/NCAR & $1979-1999$ & -1.67 & \\
& ERA-40 & $1979-1999$ & -2.2 & \\
& AR4 & $1979-1999$ & -1.03 & \pm 0.50 \\
\hline This study & ERA-Interim & $1989-2007$ & -0.97 & \\
\hline
\end{tabular}

Table 2: Trends in global-mean tropopause pressure from previous studies. All studies use a thermal tropopause definition, with the exception of Hoinka $(1998,1999)$ who uses a latitude-dependent blended tropopause based on the thermal tropopause and the 3.5 PVU surface. Trends in the blended tropopause (this study) are shown in the final row.

Acronyms: National Centres for Environmental Prediction (NCEP); National Centre for Atmospheric Research (NCAR); Global Synthesis and Observations Panel (GSOP); Parallel Climate Model (PCM); Chemistry Climate Model (CCM); IPCC Fourth Assessment Report (AR4). 
although there is some difference due to the different periods considered. ERA40 thermal tropopause trends are much larger than the blended tropopause trends $\left(39 \mathrm{~m}\right.$ decade $^{-1},-0.8 \mathrm{hPa}$ decade $\left.^{-1}\right)$. However, in ERA-Interim thermal and blended tropopause trends are comparable (Table 1). Trends in the dynamic tropopause are slightly smaller than those in the blended tropopause (Table 1).

The ERA-Interim trend in the annual-mean globally-averaged tropopause temperature is $-0.18 \mathrm{~K}$ decade ${ }^{-1}$. This cooling is consistent with the positive height trend and a typical tropospheric lapse rate of $-6.5 \mathrm{~K} \mathrm{~km}^{-1}$ partially offset by a tropospheric warming of $0.13 \mathrm{~K} \mathrm{decade}^{-1}$.

\section{Zonal-mean trends}

Considering the trends in the zonal-mean annual-mean tropopause, Figure 1a shows that the positive trend in height outside the tropics and high latitudes is 25 to $100 \mathrm{~m}$ decade $^{-1}$ (corresponding to a 1 to $3 \mathrm{hPa}$ decade $^{-1}$ decrease in pressure). The trends in the zonal-mean annual-mean tropopause in the tropics are not significantly different from zero at the $5 \%$ level. The largest positive height trends are found in the sub-tropics, and will be discussed in detail in Section 8 .

Outside the polar regions there is a marked antisymmetry between the temperature and height trends (Figure 1b), with the cooling being consistent with the rising trend, a typical tropospheric lapse rate and a tropospheric warming trend in the range $0.10-0.15 \mathrm{~K}_{\text {decade }}{ }^{-1}$.

Figure 1c shows trends in zonal-mean zonal wind at the tropopause, alongside a climatology for reference. There are positive trends in zonal-mean zonal wind near $35^{\circ} \mathrm{N}\left(0.5 \mathrm{~m} \mathrm{~s}^{-1}\right.$ decade $\left.^{-1}\right)$ and $45^{\circ} \mathrm{S}\left(0.8 \mathrm{~m} \mathrm{~s}^{-1}\right.$ decade $\left.^{-1}\right)$. The maxima coincide with the latitudes of the climatological maximum zonal wind speed, which suggests an increase in the strength of the jets with time, as found by Lorenz and DeWeaver (2007). The positive trend of $1 \mathrm{~m} \mathrm{~s}^{-1}$ decade $^{-1}$ near the equator flanked near $15^{\circ} \mathrm{N}$ and $15^{\circ} \mathrm{S}$ by comparable negative values implies a broadening and weakening of the tropical easterlies. There is a weakening trend in the westerlies of the Arctic and a strengthening of those in the Antarctic.

The Antarctic tropopause (averaged from $75-90^{\circ} \mathrm{S}$ ) exhibits falling heights ($\left.89 \mathrm{~m} \mathrm{decade}^{-1}\right)$, warming $\left(0.72 \mathrm{~K} \mathrm{decade}^{-1}\right)$ and strengthening westerly winds $\left(0.39 \mathrm{~m} \mathrm{~s}^{-1}\right.$ decade $\left.^{-1}\right)$, likely associated with the increasing Southern Annular Mode (Antarctic trends are discussed further in Section 7). The Arctic tropopause also shows warming $\left(0.66 \mathrm{~K} \mathrm{decade}^{-1}\right)$, but its height trend is not significant. Here the westerlies have a weakening trend $\left(-0.72 \mathrm{~m} \mathrm{~s}^{-1}\right.$ decade $\left.^{-1}\right)$.

Figure 1d shows the annual-mean zonal-mean tropopause height trends from the blended, dynamic and thermal tropopause definitions. Significant positive trends are only identified in the tropics when the thermal tropopause is used. Trends in the height of the dynamic and blended tropopause have more zonal structure compared to those in the thermal tropopause, with larger trends in the sub-tropics and extratropics. These differences are particularly pronounced in the Southern Hemisphere $(\mathrm{SH})$. The large negative height trends seen in the 

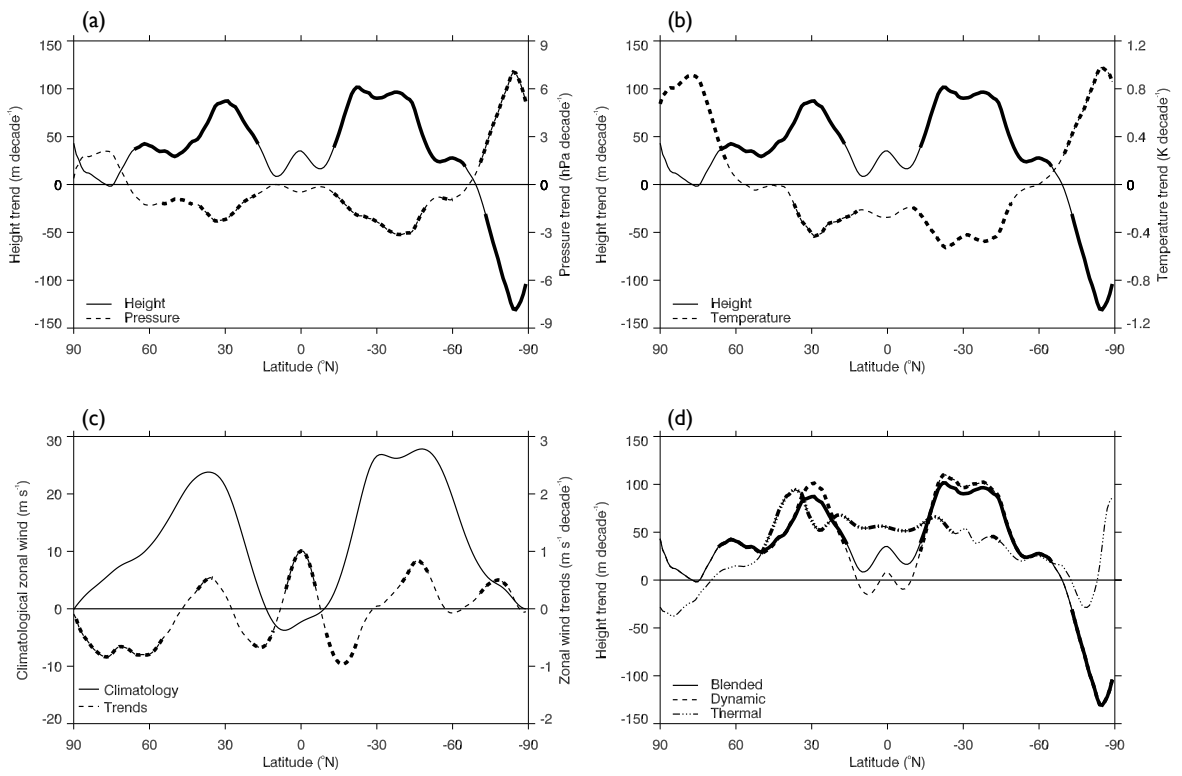

Figure 1: (a) Annual-mean zonal-mean blended tropopause height and pressure trends (m decade ${ }^{-1}$ and $\mathrm{hPa}$ decade ${ }^{-1}$ ) from ERA-Interim (1989-2007). (b) Tropopause height and temperature trends (m decade ${ }^{-1}$ and $\left.\mathrm{K}_{\text {decade }}{ }^{-1}\right)$. (c) Tropopause level zonal-mean zonal wind climatology and trends $\left(\mathrm{m} \mathrm{s}^{-1}\right.$ and $\mathrm{m} \mathrm{s}^{-1}$ decade $^{-1}$ ). (d) Annual-mean zonal-mean blended, dynamic and thermal tropopause height $\left(\mathrm{m}\right.$ decade $\left.{ }^{-1}\right)$. Bold lines indicate where trends are significant at or above the $5 \%$ level. 

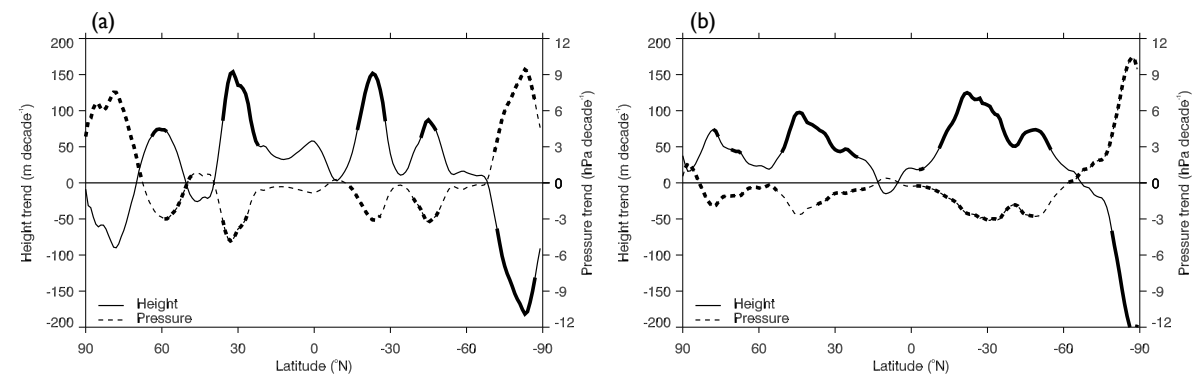

Figure 2: Seasonal-mean zonal-mean blended tropopause height and pressure trends (m decade ${ }^{-1}$ and $\mathrm{hPa}$ decade ${ }^{-1}$ ) from ERA-Interim (1989-2007). (a) December to February mean. (b) June to August mean. Bold lines indicate where trends are significant at or above the $5 \%$ level.

dynamic and blended tropopause in the SH high latitudes are not found in the thermal tropopause in the annual-mean case.

Blending between the dynamic tropopause and the lower of the dynamic and thermal tropopause, $h_{m}$ (Section 3), typically occurs at latitudes equatorward of $\pm 30^{\circ}$. However, the height of the blended tropopause is only equal to $h_{m}$ in a very narrow band along the equator. This can be seen in Figure 1 of Part 1, and is reflected in Figure 1d where the trends in the thermal, dynamic and blended tropopauses are distinct throughout the tropics.

Zonal-mean seasonal-mean trends for DJF and JJA are shown in Figure 2. The overall pattern of the zonal-mean trends in DJF and JJA are similar, but with more latitudinal structure in DJF. In DJF there are maximum positive trends in tropopause height near $30^{\circ} \mathrm{N}$ and $25^{\circ} \mathrm{S}\left(+150 \mathrm{~m}\right.$ decade $\left.^{-1}\right)$, and secondary peaks at $60^{\circ} \mathrm{N}, 45^{\circ} \mathrm{S}\left(\sim 75 \mathrm{~m} \mathrm{decade}{ }^{-1}\right)$, and the Equator $(+60 \mathrm{~m}$ decade $\left.^{-1}\right)$. The large negative trends in the Antarctic are seen to occur and be significant in both seasons.

In JJA there are local peaks in the tropopause height trends at $80^{\circ} \mathrm{N}, 45^{\circ} \mathrm{N}$, $25^{\circ} \mathrm{S}$, and $50^{\circ} \mathrm{S}\left(+75,100,125\right.$, and $75 \mathrm{~m}$ decade $\left.^{-1}\right)$. Compared with DJF, these maxima are smaller, but the regions of significance, and the global-mean trend (see Table 1), are larger. As in DJF, there is also a significant negative height trend in the SH high latitudes. Comparison of Figures 1a and 2 shows that the annual-mean zonal-mean trends resemble the JJA trends more strongly than those for DJF, reflecting the similarity between the trends in JJA and the equinoctial seasons.

\section{Geographical structure of trends}

The spatial structure of the trends is shown in Figure 3. The dominant feature is the positive height trends in the sub-tropics in both DJF and JJA, along with 

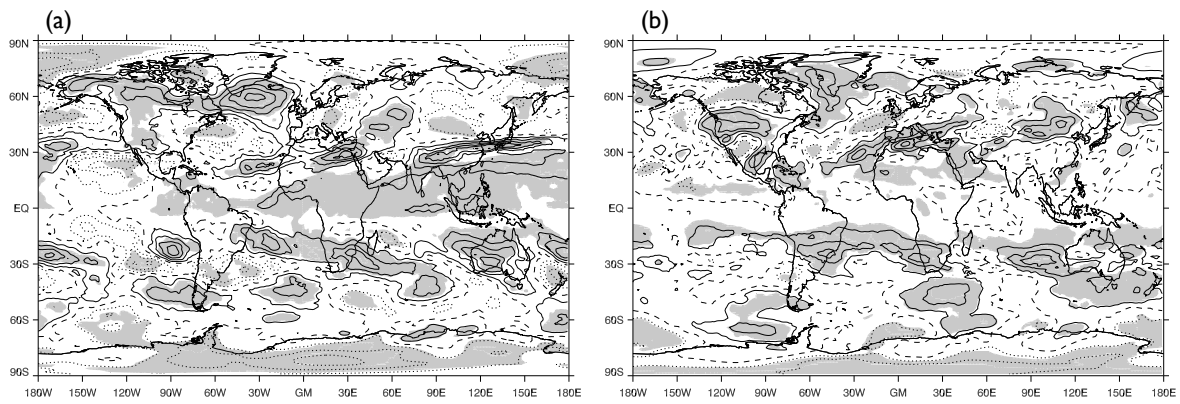

Figure 3: Trends in blended tropopause height (a) DJF and (b) JJA for ERAInterim (1989-2007). Solid contours show positive trends, the zero line is dashed, and negative contours are dotted. The contour interval is $100 \mathrm{~m} \mathrm{decade}{ }^{-1}$. Shading highlights where the trends are significant at or above the $5 \%$ level.

positive trends in the tropics in DJF. These features will be discussed further in Section 8. The Antarctic trends will be discussed in Section 7.

There are tripole structures in height over the North Pacific and North Atlantic in DJF (Figure 3a). Over the North Pacific in DJF an increase in height near $35^{\circ} \mathrm{N}$ is flanked in the east by decreases in height. Over the North Atlantic there is a decrease in height in the mid-latitudes flanked by increases. The latter is suggestive of a relationship with the negative North Atlantic Oscillation (NAO) pattern. The NAO index decreases over the period of the climatology; the difference between the tropopause pressures in the north and south of the North Atlantic region correlates well with the NAO index, with $\mathrm{r}^{2}=0.6$. The correlations between tropopause height over the North Pacific with the West Pacific Pattern (Wallace and Gutzler, 1981) and the North Pacific Index (Trenberth and Hurrell, 1994) are weaker.

Figure 3a shows significant positive height trends across most of the tropical region in DJF, with the exception of negative height trends over the central Pacific. These negative trends have a similar structure to the La Niña anticyclones, reflecting the large number of La Niña years in the climatology. Figure 2 shows that the zonal-mean height trends in the tropics in DJF are $\sim 50 \mathrm{~m} \mathrm{decade}^{-1}$. However, Figure 3a shows that local trends can be more than double this in the eastern hemisphere, and are statistically significant at the $5 \%$ level.

Height trends in JJA (Figure 3b) are generally smaller than those in DJF, but are still significant in several regions. There are increases in height in the SH sub-tropics and extratropics, as in DJF, although the trends are weaker over the South Pacific. There is a weaker tripole structure over the North Atlantic, shifted polewards and eastwards compared to the DJF pattern. Over North America there is an increase in height in the region $40^{\circ} \mathrm{N}$ to $50^{\circ} \mathrm{N}$. 


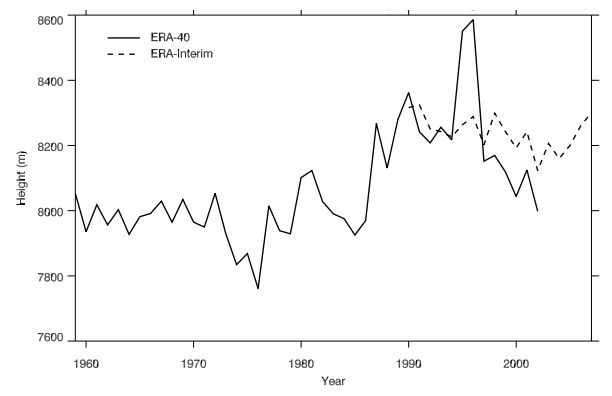

Figure 4: $75-90^{\circ} \mathrm{S}-$ mean annual-mean tropopause height $(\mathrm{m})$ from ERA-40 (solid) and ERA-Interim (dashed).

\section{$7 \quad$ Antarctic trends}

The Antarctic is the only substantial region with persistent statistically significant negative height trends. These trends are present in all seasons, and they do not extend far beyond the Antarctic coastline, if at all. It can be seen in Figure 3 that the trends are larger in DJF compared to JJA, with local maxima in excess of $-300 \mathrm{~m}$ decade $^{-1}$ compared to $-200 \mathrm{~m}$ decade $^{-1}$. This is also true for the regional average trends for $75^{\circ} \mathrm{S}-90^{\circ} \mathrm{S}\left(-147 \mathrm{~m}\right.$ decade ${ }^{-1}$ in DJF, $-83 \mathrm{~m}$ decade $^{-1}$ in JJA, both significant at the $5 \%$ level).

Time series of annual-mean Antarctic tropopause height from ERA-40 and ERA-Interim are shown in Figure 4. An increasing trend in tropopause height can be seen in ERA-40 from the late 1970s to 1990, followed by a general decrease in height. This decrease in height is also seen in ERA-Interim (albeit smaller), and can also be seen in time series of both dynamic and thermal tropopause height (not shown). There is a suggestion of a return to positive or zero trends towards the end of ERA-Interim. It is also very clear from Figure 4 that the choice of end points is critical to the both the magnitude and sign of the trend.

Previous studies (e.g. Santer et al., 2004; Seidel and Randel, 2006; Schmidt et al., 2010) have reported increases in Antarctic tropopause height. However, in each of these cases, the trend from ERA-Interim would also be positive if the end points of the analysis were chosen to match those in the earlier work.

The negative tropopause height trends for periods beginning after 1989 may be the result of stratospheric ozone recovery. Ozone depletion causes the height of the tropopause to increase, and vice versa (Santer et al., 2004). Although ozone recovery did not begin until 2000, tropospheric halogen loading peaked in 1993 (Eyring et al., 2010). Hence, it is possible that trends for 1989-2007 are reflecting a period of small changes in lower stratospheric ozone, followed by a period of ozone recovery, which will result in negative trends in tropopause height. Negative trends can be seen in the region $60-90^{\circ} \mathrm{S}$ in some model simulations in Gettelman et al. (2010) in the decades immediately following 2000, and in the 1990s and 2000s in some CCM results in Son et al. (2009a) for $45-90^{\circ} \mathrm{S}$. 


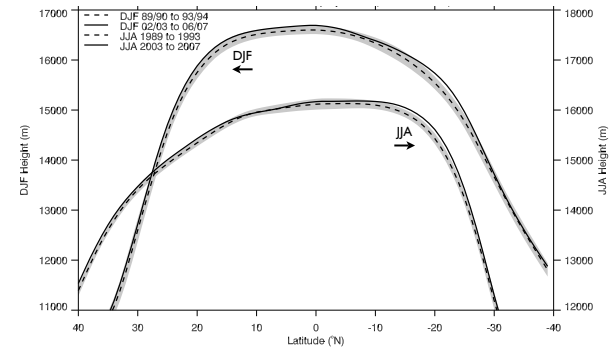

Figure 5: Zonal mean blended tropopause height from ERA-Interim. The average for the first (dashed line) and last 5 years (solid line) of the climatology are shown for DJF and JJA. Shading shows the average of the first five years \pm the de-trended standard deviation for the whole of ERA-Interim. The left and right hand axes refer to DJF and JJA respectively.

The leading mode of variability in geopotential height and zonal wind in the $\mathrm{SH}$ is the SH Annular Mode (SAM), which is defined as the difference of zonalmean sea-level pressure between $40^{\circ} \mathrm{S}$ and $65^{\circ} \mathrm{S}$. A significant increase in the SAM has been observed since 1958 (Marshall, 2003) (pressures over Antarctica becoming lower relative to pressure in the mid-latitudes). This increase in the SAM is linked to a strengthening of the circumpolar vortex, and intensification of the westerlies around Antarctica. Such an intensification of the westerlies can be seen in Figure 1c.

\section{Tropical broadening}

A prominent feature in Figures 1 to 3 is the large positive trends in the subtropics. Latitudinal gradients of tropopause height are large here, and the large height trends are indicative of a poleward expansion of the region of high tropopause height characteristic of the tropics.

The zonal mean of tropical and sub-tropical tropopause heights, averaged over the first and last five years of ERA-Interim, is shown in Figure 5. In both DJF and JJA the average height for the last five years is greater than or equal to the average height for the first five years and the de-trended standard deviation of height for most latitudes. It is apparent from Figure 5 that expansion into the $\mathrm{SH}$ makes a greater contribution to the total broadening than that into the $\mathrm{NH}$, a feature of this expansion that has also been observed by $\mathrm{Hu}$ and $\mathrm{Fu}(2007)$, and Seidel and Randel (2007). The rate of expansion into the SH also shows less seasonal variation than that into the $\mathrm{NH}$.

Several different metrics have been used in previous studies to identify the edge of the 'tropical tropopause' in order to quantify broadening. These include the location where the thermally-driven jet first becomes unstable ( $\mathrm{Lu}$ et al., 2007), the number of 'high tropopause' days (Seidel and Randel, 2007), and 
specified values of outgoing long wave radiation (Johanson and $\mathrm{Fu}, 2009$ ). The broadening signal appears to be consistent across the different metrics (Seidel et al., 2008). The sensitivity to three different definitions of the tropical belt is explored here.

Seidel and Randel (2007) define the tropical belt as the region where the thermal tropopause is higher than a critical altitude of $15 \mathrm{~km}$ for more than 100,200 , or 300 days per year. Their metric is adapted here, and the tropical blended tropopause is defined as having a seasonal-mean zonal-mean altitude of $15 \mathrm{~km}$ or more. The rate of expansion was evaluated at $15,15.5$, and $16 \mathrm{~km}$ by taking the difference in latitude between the means of the first and last five years of the climatology. The mean expansion over these altitudes was taken as the rate of tropical broadening. The total rate of expansion in ERA-Interim (1989-2007) is $0.9^{\circ}$ decade $^{-1}$ in both DJF and JJA. In ERA-40 (1958-2001), the rate is smaller $\left(0.7^{\circ}\right.$ decade $^{-1}$ in both seasons $)$. These values are broadly consistent with previous estimates, which range from $0.4^{\circ}$ decade $^{-1}$ (Birner, 2010 ) to $3.1^{\circ}$ decade $^{-1}$ (Seidel and Randel, 2007). Note that Birner (2010) also identified a contraction of the tropics when using his 'objective height definition' with the Japanese reanalysis, although this was only small, and not consistent with the results from the ERA-40, NCEP/NCAR and NCEP/DOE reanalyses.

Figure 3 shows that the large positive trends in zonal-mean height in the NH sub-tropics seen in Figure 2 are due mostly to positive height trends in the eastern hemisphere. This is especially the case in DJF when there are height increases of up to $+400 \mathrm{~m} \mathrm{decade}^{-1}$ over the east Mediterranean, south-east Asia and Japan (Figure 3a). There are only small or negative trends in the sub-tropics in the western half of the NH. This is in contrast to the findings of Seidel and Randel (2007) who found that the increases in sub-tropical tropopause height were restricted to the western hemisphere. Trends in the $\mathrm{SH}$ are more zonally uniform, though still larger in the eastern hemisphere, with positive trends of up to $+400 \mathrm{~m} \mathrm{decade}^{-1}$ at $20-30^{\circ} \mathrm{S}$. In JJA the trends in the NH sub-tropics are weaker, with significant positive height trends only in the region $45^{\circ} \mathrm{W}$ to $45^{\circ} \mathrm{E}$ (Figure $3 \mathrm{~b}$ ). In the $\mathrm{SH}$, the change is very similar to, but slightly weaker than, that in DJF.

The rate of tropical broadening can also be calculated from the zonal trends seen in Figure 2. The large positive height trends in the sub-tropics in both seasons are at similar latitudes to the steep gradients in tropopause height. The average height trend and the latitudinal gradient in tropopause height can be combined to give an alternative measure of the expansion rate. Here the rate of expansion is defined as the ratio of the average height trends and average height gradients for a specified latitude range.

The rate of tropical broadening in ERA-Interim (1989-2007), using the blended and dynamic tropopause definitions, is shown in Table 3. Results from the use of averages over a $3^{\circ}, 5^{\circ}$ and $9^{\circ}$ latitude range, centred on the latitude with the maximum sub-tropical trend, are shown. The rate of expansion is sensitive to the number of latitudes over which the calculation is performed, ranging from $2.0^{\circ}$ decade $^{-1}\left(1.6^{\circ}\right.$ decade $\left.^{-1}\right)$ for the $3^{\circ}$ latitude range to $1.4^{\circ}$ decade $^{-1}\left(1.1^{\circ}\right.$ decade $^{-1}$ ) for the $9^{\circ}$ range for DJF (JJA). However, the contribution from each 


\begin{tabular}{ccccccc}
\hline & \multicolumn{2}{c}{$3^{\circ}$} & \multicolumn{2}{c}{$5^{\circ}$} & \multicolumn{2}{c}{$9^{\circ}$} \\
\hline Blended & Rate & \% SH & Rate & \% SH & Rate & $\%$ SH \\
\hline DJF & 2.0 & 72 & 1.7 & 72 & 1.4 & 71 \\
JJA & 1.6 & 54 & 1.3 & 53 & 1.1 & 53 \\
\hline Dynamic & & & & & & \\
\hline DJF & 2.2 & 70 & 1.7 & 70 & 1.5 & 68 \\
JJA & 1.7 & 56 & 1.4 & 55 & 1.2 & 56 \\
\hline
\end{tabular}

Table 3: Rates of tropical broadening $\left[{ }^{\circ}\right.$ decade $\left.^{-1}\right]$ for an ERA-Interim (19892007) blended and dynamic tropopause, for different widths of latitudinal averaging centred on the latitude of maximum height trend.

hemisphere to the total expansion is not sensitive to this choice. Expansion into the $\mathrm{SH}$ accounts for $\sim 72 \%$ of the total expansion in DJF, and $\sim 55 \%$ in JJA.

The rate of tropical broadening is again smaller in ERA-40 (1979-2001) compared to ERA-Interim (1989-2007): $1.2{ }^{\circ}$ decade $^{-1}$ in DJF and $0.6{ }^{\circ}$ decade $^{-1}$ in JJA when a $3^{\circ}$ latitude range is considered. In contrast to the ERA-Interim result, in ERA-40 the largest contribution to the total expansion always comes from the summer hemisphere.

The latitudes where large sub-tropical tropopause height trends occur coincide with the latitudes where the blended tropopause definition begins to deviate from the dynamic tropopause definition. To explore the possibility of a sensitivity of the rate of broadening to the blending process, the trends have been determined separately for the two alternative data sets based on the dynamic and thermal tropopause definitions. It can be seen in Table 3 that using the dynamic definition alone results in very similar estimates for tropical broadening to those using the blended definition. The values are slightly larger, which is consistent with the generally slightly smaller values found using the thermal definition. It can be concluded that the blending process that often occurs in the sub-tropical region is not critical in the estimates obtained for tropical broadening.

The maximum negative zonal wind trends occur in regions of westerly winds (Figure 1c). If the time taken for these westerly winds to reduce (linearly) to zero is computed, this gives an alternative metric for the rate of expansion i.e.:

$$
\text { Rate }=\frac{l a t B-l a t A}{\left(u / \frac{d u}{d t}\right)_{B}}
$$

where lat $A$ is where the zonal-mean climatological zonal-wind $(u)$ is 0 , and lat $B$ is the latitude with the largest negative zonal-wind trends. This method avoids the arbitrary thresholds required by the previous two definitions. Using this method, the DJF and JJA broadening trends are $1.0^{\circ}$ decade $^{-1}$ and $2.2^{\circ}$ decade $^{-1}$ respectively. About $70 \%$ of the total expansion is into the $\mathrm{SH}$ in both seasons.

These rates of tropical broadening calculated from the trends in zonal-mean 


\begin{tabular}{ccccc}
\hline & \multicolumn{2}{c}{ DJF } & \multicolumn{2}{c}{ JJA } \\
\hline Metric & Rate & \% SH & Rate & $\%$ SH \\
\hline Critical height & 0.9 & 80 & 0.9 & 60 \\
Height trends $\left(3^{\circ}\right)$ & 2.0 & 72 & 1.6 & 54 \\
Zonal wind trends & 1.0 & 70 & 2.2 & 70 \\
\hline
\end{tabular}

Table 4: Rates of tropical broadening $\left[{ }^{\circ}\right.$ decade $\left.^{-1}\right]$ for the ERA-Interim (19892007) blended tropopause, for three different metrics, along side the percentage of the total expansion that occurs into the Southern Hemisphere.

zonal-winds are larger than, but still comparable to, those calculated using zonal-mean tropopause height.

A summary of the trends from the three broadening metrics is shown in Table 4. The different magnitude of the trends, and the contributions to total expansion from each hemisphere, demonstrate the sensitivity of the expansion to the definition of the tropical belt, but also indicate a general robustness of the overall result amongst the definitions.

\section{Conclusions}

Global and regional trends have been presented for annual and solsticial seasonal means using a new definition of the tropopause that blends thermal and dynamic definitions. For ERA-Interim (1989-2007) global-mean tropopause height and pressure trends are $+47 \mathrm{~m}$ decade ${ }^{-1}$ and $-1.0 \mathrm{hPa}$ decade $^{-1}$, and for ERA-40 (1979-2001) they are similar: $+39 \mathrm{~m}$ decade $^{-1}$ and $-0.8 \mathrm{hPa}$ decade $^{-1}$. The ERA-Interim tropopause temperature trend is $-0.18 \mathrm{~K} \mathrm{decade}^{-1}$. These values are generally smaller than those found in previous studies using the thermal tropopause definition, which typically lie in the range from -1 to $-2 \mathrm{hPa}$ decade $^{-1}$ (e.g. Sausen and Santer, 2003; Santer et al., 2003b, 2004; Seidel and Randel, 2006).

Trends in the tropical tropopause are small, but at the latitudes of the subtropical jets they are almost double the global values. The Antarctic tropopause shows warming, decreasing height, and increasing westerly wind. The Arctic tropopause is also warming, but with decreasing westerly winds.

The Antarctic is the only substantial region with sustained statistically significant negative trends in tropopause height. Comparison of ERA-Interim and ERA-40 trends since 1989 with trends in ERA-40 from earlier periods, and analysis of time series of tropopause height reveals a change in sign of Antarctic tropopause height trends between the 1980s and 1990s. Although blended tropopause trends are more robust in this region, a similar change in sign can also be seen in thermal tropopause trends.

Trends in tropical tropopause height and zonal winds suggest a broadening of the tropical region. This broadening has been quantified using three metrics, 
based on a critical tropopause altitude, zonal-mean height trends, and zonalmean zonal-wind trends. Rates of expansion are found to lie in the range $0.9^{\circ}$ decade $^{-1}$ to $2.2^{\circ}$ decade $^{-1}$ for ERA-Interim (1989-2007), with between $54 \%$ and $80 \%$ of the total expansion resulting from expansion into the SH. Expansion estimates from the three metrics used in this work lie within the range of estimates presented in previous studies (0.4 to $3.1^{\circ}$ decade $^{-1}$ ), although most are in the range from 1 to $2^{\circ}$ decade $^{-1}$, (e.g. Seidel and Randel, 2007; Hu and Fu, 2007; Seidel et al., 2008).

\section{Acknowledgements}

This work was funded by the U.S. Federal Aviation Administration (FAA) under contract award DTRT57-07-P-80162. Any opinions, findings, and conclusions or recommendations expressed in this material are those of the authors and do not necessarily reflect the views of the research sponsor. We also acknowledge the use of ERA-Interim/40 data produced by ECMWF and provided by the British Atmospheric Data Centre and National Centre for Atmospheric ScienceClimate. Thanks to Dian Seidel and three anonymous reviewers for helpful comments on an earlier version of this manuscript.

\section{References}

Birner T. 2010. Recent widening of the tropical belt from global tropopause statistics: Sensitivities. J. Geophys. Res., 115: D23109.

Dee DP, Uppala SM, Simmons AJ, Berrisford P, Poli P, Kobayashi S, Andrae U, Balmaseda A, Balsamo G, Bauer P, Bechtold P, Beljaars ACM, van de Berg L, Bidlot J, Bormann N, Delsol C, Dragani R, Fuentes M, Geer AJ, Haimberger L, Healy SB, Hersbach H, Hólm EV, Isaksen L, Kållberg P, Köhler M, Matricardi M, McNally AP, Monge-Sanz BM, Morcrette J-J, Park B-K, Peubey C, de Rosnay P, Tavolate C, Thépaut J-N, Vitart F. 2011. The ERA-Interim reanalysis: configuration and performance of the data assimilation system. Q. J. R. Meteorol. Soc. 137: 553-597.

Eyring V, Cionni I, Bodeker GE, Charlton-Perez AJ, Kinnison DE, Scinocca JF, Waugh DW, Akiyoshi H, Bekki S, Chipperfield MP, Dameris M, Dhomse S, Frith SM, Garny H, Gettelman A, Kubin A, Langematz U, Mancini E, Marchand M, Nakamura T, Oman LD, Pawson S, Pitari G, Plummer DA, Rozanov E, Shepherd TG, Shibata K, Tian W, Braesicke P, Hardiman SC, Lamarque JF, Morgenstern O, Pyle JA, Smale D, Yamashita Y. 2010. Multi-model assessment of stratospheric ozone return dates and ozone recovery in CCMVal-2 models. Atmos. Chem. Phys 10: 9451-9472. DOI:10.5194/acp-10-9451-2010.

Gettelman A, Hegglin MI, Son S-W, Kim J, Kujiwara M, Birner T, Kremser S, Rex M, Añel JA, Akiyoshi H, Austin J, Bekki S, Braesike P, Brühl 
C, Butchart N, Chipperfield M, Dameris M, Dhomse S, Garny H, Hardiman SC, Jöckel P, Kinnison DE, Lamarque JF, Mancini E, Marchand M, Michou M, Morgenstern O, Pawson S, Pitari G, Plummer D, Pyle JA, Rozanov E, Scinocca J, Shepherd TG, Shibata K, Smale D, Teyssédre H, Tian W. 2010. Multimodel assessment of the upper troposphere and lower stratosphere: Tropics and global trends. J. Geophys. Res. 115: D00M08. DOI:10.1029/2009JD013638.

Hoinka KP. 1999. Temperature, humidity, and wind at the global tropopause. Mon. Weather Rev. 127: 2248-2265.

Hoskins BJ, McIntyre ME, Robertson WA. 1985. On the use and significance of isentropic potential vorticity maps. Q. J. R. Meteorol. Soc. 111 (470): 877-946.

$\mathrm{Hu}$ Y, Fu Q. 2007. Observed poleward expansion of the Hadley circulation since 1979, Atmos. Chem. Phys. 7(19): 5229-5236.

Johanson CM, Fu Q. 2009. Hadley cell widening: model simulations versus observations, J. Climate 22: 2713-2725. DOI:10.1175/2008JCLI2620.1

Kunz A, Konopka P, Müller R, Pan LL. 2011. Dynamical tropopause based on isentropic potential vorticity gradients. J. Geophys. Res. 116: D01110.

Lorenz DJ, DeWeaver, ET. 2007. The tropopause height and the zonal wind response to global warming in the IPCC scenario integrations. J. Geophys. Res. 112: D10119. DOI:10.1029/2006JD008087

Lu J, Vecchi GA, Reichler T. 2007. Expansion of the Hadley cell under global warming. Geophys. Res. Lett. 34: L06805. DOI: 10.1029/2006GL028443.

Marshall GJ. 2003. Trends in the Southern Annular Mode from observations and reanalyses. J. Climate 16: 4134-4143.

Randel WJ, Wu F, Gaffen DJ. 2000. Interannual variability of the tropical tropopause derived from radiosonde data and NCEP reanalyses. J. Geophys. Res. 105(D12): 15509-15524. DOI:10.1029/2000JD900155

Reichler T, Dameris M, Sausen R. 2003. Determining the tropopause height from gridded data. Geophys. Res. Lett. 30: 2042.

Santer BD, Wehner MF, Wigley TML, Sausen R, Meehl GA, Taylor KE, Ammann C, Arblaster J, Washington WM, Boyle JS, Brüggemann W. 2003a. Contributions of anthropogenic and natural forcing to recent tropopause height changes. Science 301(5632): 479-483. DOI: 10.1126/science.1084123

Santer BD, Sausen R, Wigley TML, Boyle JS, AchutaRao K, Doutriaux C, Hansen JE, Meehl GA, Roeckner E, Ruedy R, Schmidt G, Taylor KE. 2003b. Behavior of tropopause height and atmospheric temperature in models, reanalyses, and observations: Decadal changes. J. Geophys. Res. 108(D1): 4002. DOI:10.1029/2002JD002258 
Santer BD, Wigley TML, Simmons AJ, Kållberg PW, Kelly GA, Uppala AM, Ammann C, Boyle JS, Brüggemann W, Doutriaux C, Fiorino M, Mears C, Meehl GA, Sausen R, Taylor KE, Washington WM, Wehner MF, Wentz FJ. 2004. Identification of anthropogenic climate change using a second-generation reanalysis. J. Geophys. Res. 109: D21104. DOI: 10.1029/2004JD005075.

Sausen R, Santer BD. 2003. Use of changes in tropopause height to detect human influences on climate. Meteorol. Z. 12(3): 131-136. DOI:10.1127/09412948/2003/0012-0131.

Schmidt T, Wickert J, Beyerle G, Heise S. 2008. Global tropopause height trends estimated from GPS radio occultation data. Geophys. Res. Lett. 35: L11806.

Schmidt T, Wickert J, Haser A. 2010. Variability of the upper troposphere and lower stratosphere observed with GPS radio occultation bending angles and temperatures. Advances in Space Research 46: 150-161.

Seidel DJ, Ross RJ, Angell JK, Reid GC. 2001. Climatological characteristics of the tropical tropopause as revealed by radiosondes. J. Geophys. Res. 106: $7857-7878$.

Seidel DJ, Randel WJ. 2006. Variability and trends in the global tropopause estimated from radiosonde data. J. Geophys. Res. 111: D21101. DOI: 10.1029/2006JD007363

Seidel DJ, Randel WJ. 2007. Recent widening of the tropical belt: Evidence from tropopause observations. J. Geophys. Res. 112: D20113. DOI: 10.1029/2007JD008861

Seidel DJ, Fu Q, Randel WJ, Reichler TJ. 2008. Widening of the tropical belt in a changing climate. Nat. Geosci. 1: 21-24. DOI:10.1038/ngeo.2007.38

Son S-W, Polvani LM, Waugh DW, Birner T, Akiyoshi H, Garcia RR, Gettelman A, Plummer DA, Rozanov E. 2009. The impact of stratospheric ozone recovery on tropopause height trends. J. Climate 22: 429-445. DOI: $10.1175 / 2008 J C L I 2215.1$

Trenberth KE, Hurrell JW. 1994. Decadal atmosphere-ocean variations in the Pacific. Clim. Dynam. 9: 303-319.

Uppala SM, Kållberg PW, Simmons AJ, Andrae U, Da Costa Bechtold V, Fiorino M, Gibson JK, Haseler J, Hernandez A, Kelly GA, Li X, Onogi K, Saarinen S, Sokka N, Allan RP, Andersson E, Arpe K, Balmaseda MA, Beljaars ACM, Van De Berg L, Bidlot J, Bormann N, Caires S, Chevallier F, Dethof A, Dragosavae M, Fisher M, Fuentes M, Hagemann A, Hólm E, Hoskins BJ, Isaksen L, Janssen PAEM, Jenne R, Mcnally AP, Mahfouf JF, Morcrette J-J, Rayner NA, Saunders RW, Simon P, Sterl A, Trenberth 
KE, Untch A, Vasiljevie D, Viterbo P, Woollen, J. 2005. The ERA-40 reanalysis, Q. J. R. Meteorol. Soc. 131:2961-3012. DOI: 10.1256/qj.04.174

Wallace JM, Gutzler DS. 1981. Teleconnections in the geopotential height field during the Northern Hemisphere winter. Mon. Weather. Rev. 109: 784-812.

Wilcox LJ, Hoskins BJ, Shine KP. 2011. A global blended tropopause based on ERA data. Part I: Climatology. Q. J. R. Meteorol. Soc., submitted.

World Meteorological Organization. 1957. Meteorology - a three-dimensional science. WMO Bull. 6: 134-138.

Zhou X-L, Geller MA, Zhang M. 2001. Cooling trend of the tropical cold point tropopause temperatures and its implications. J. Geophys. Res. 106: $1511-1522$. 